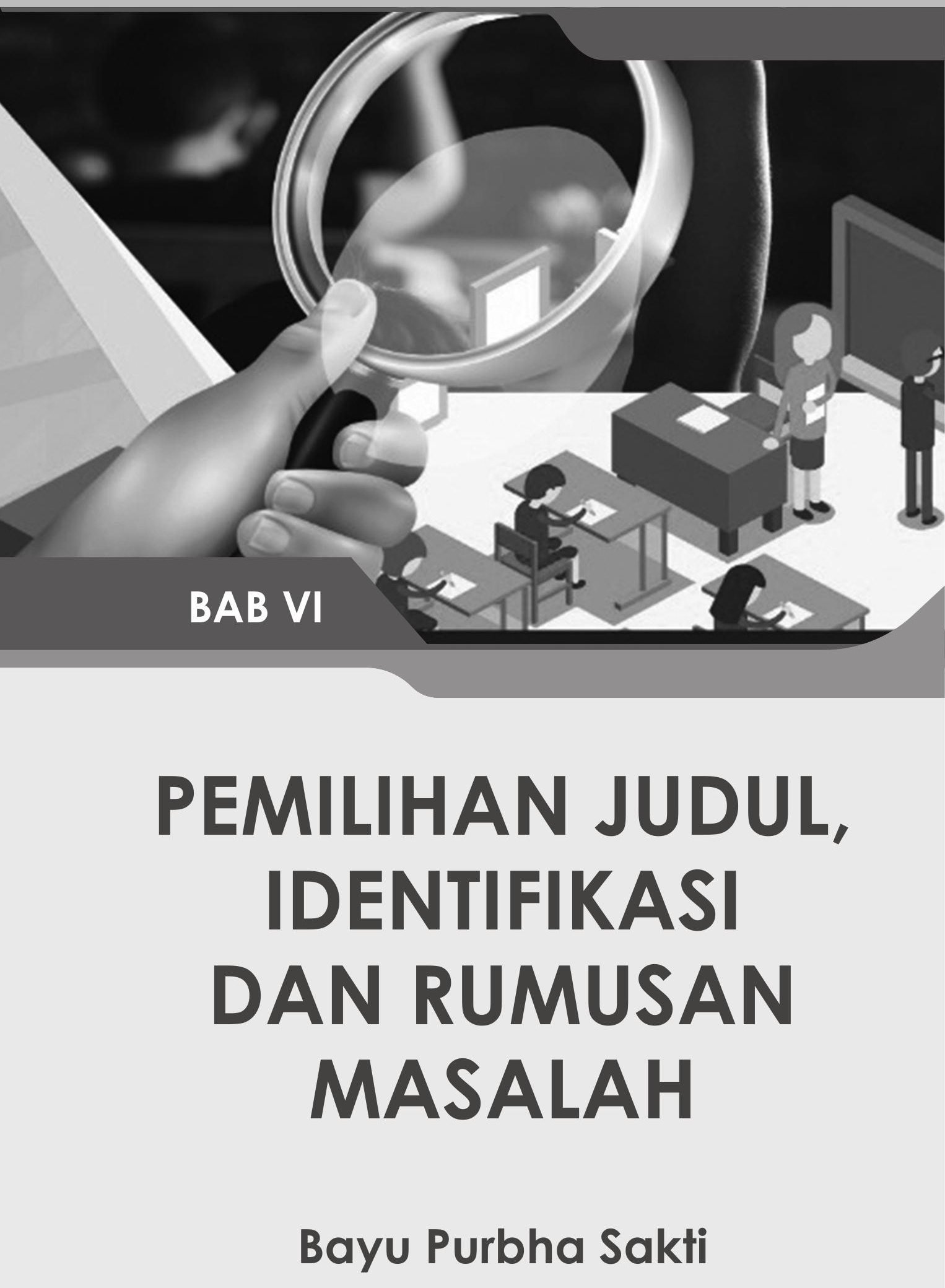




\section{A. SINOPSIS}

Judul penelitian yang dipilih dari proposal penelitian, skripsi, tesis, atau disertasi merupakan suatu rumusan gagasan yang memenuhi suatu fenomena, gejala, bahkan kejadian dari lingkungan tertentu yang dibuat menjadi objek kajian. Judul penelitian yang ditulis harus menunjukkan kejelasan dan ketegasan berkaitan variabel yang akan digunakan. Variabel bebas adalah faktor yang mendahului dan variabel terikat adalah faktor yang menjadi akibat. Judul penelitian tindakan kelas harus berfokus pada subyek orang dan tempat dimana dilakukan penelitian yang sama. Kata yang digunakan dalam pemilihan judul akan memberikan pengetahuan sekilas lebih awal untuk pembaca.

Identifikasi masalah merupakan suatu cara untuk menuliskan pernyataan-pernyataan masalah yang berada di dalam latar belakang masalah. Identifikasi masalah ditulis berupa kalimat-kalimat pernyataan yang menunjukan masalah. Upaya perbaikan yang dilakukan ditentukan oleh pemilihan dan identifikasi masalah yang tepat. Masalah yang didapatkan dari kegiatan pembelajaran dapat diidentifikasi dan diteliti. Rancangan penelitian tindakan kelas akan menentukan terhadap masalah-masalah yang ditulis dan diidentifikasi.

Rumusan masalah merupakan suatu cara untuk menuliskan pertanyaan-pertanyaan masalah yang didapatkan dari latar belakang masalah. Rumusan masalah ditulis berupa kalimat pertanyaan yang berkaitan dengan judul dan permasalahan penelitian. Kata dan kalimat yang akan dituliskan di rumusan masalah harus mempertimbangkan variabel penelitian yang sudah ditulis. Rumusan masalah ditulis berupa kalimat-kalimat pertanyaan yang menanyakan solusi dari masalah. Masalah-masalah tersebut juga harus ditanyakan sesuai dengan karakter pertanyaan penelitian tindakan kelas. 


\section{B. PEMILIHAN JUDUL}

Pemilihan judul penelitian merupakan bagian awal dari sebuah kegiatan penelitian. Sebelum merancang proposal, penting untuk memiliki gambaran tentang struktur umum atau garis besar topik dan urutannya (Creswell \& Creswell, 2018). Judul penelitian yang dipilih dari proposal penelitian, skripsi, tesis, atau disertasi merupakan suatu rumusan gagasan yang memenuhi suatu fenomena, gejala, bahkan kejadian dari lingkungan tertentu yang dibuat menjadi objek kajian. Peneliti dapat menulis tentang penelitian untuk tujuan mengembangkan pemahaman tanpa khawatir apakah orang lain akan menyetujui tulisan atau alasan tersebut (Harris, 2020). Tulisan judul penelitian yang atraktif akan menarik minat dan antusias pembaca untuk memfokuskan penglihatannya.

Pemilihan judul penelitian tindakan kelas dapat dilakukan dengan menentukan variabel penelitian yang akan digunakan. Menggunakan judul dan subjudul adalah salah satu cara sederhana untuk menyediakan struktur organisasi untuk tulisan dan membuat struktur itu jelas bagi orang lain (Leedy \& Ormrod, 2021). Judul penelitian yang ditulis harus menunjukkan kejelasan dan ketegasan berkaitan variabel yang akan digunakan. Variabel bebas adalah faktor yang mendahului dan variabel terikat adalah faktor yang menjadi akibat. Kedua variabel tersebut merupakan bagian dari masalah yang dituliskan di judul. Pelaksanaan penelitian tindakan kelas dimulai dari kegiatan permasalahan akademik yang didapatkan di ruang lingkup supervisi klinis dan dibutuhkan segera pemecahannya (Huda, 2020). Pemilihan judul yang tepat akan membantu peneliti untuk memiliki gambaran informasi awal mengenai rancangan penelitian.

Pemilihan judul penelitian tindakan kelas dapat dilakukan dengan menentukan orang dan tempat dimana kegiatan penelitian akan dilakukan. Penelitian tindakan kelas adalah kajian dengan sistem untuk memperbaiki implementasi praktek pendidikan yang dilakukan guru disertai tindakan-tindakan proses pembelajaran (Nurdin, 2016). Judul penelitian tindakan kelas harus berfokus pada subyek orang 
dan tempat dimana dilakukan penelitian yang sama. Hasil penelitian tindakan kelas dapat digunakan dan dibagikan sebagai pengalaman dengan guru atau praktisi yang mengajar dalam bidang studi yang sama (Rahardjo, 2015). Penelitian tindakan kelas biasanya dilakukan di dalam atau di luar kelas. Penelitian tindakan kelas adalah salah satu cara yang dapat digunakan pendidik dalam meningkatkan atau memperbaiki proses pembelajaran dalam layanan pendidikan (Susilowati, 2018). Pemilihan judul menggunakan penulisan kata meningkatkan akan membantu peneliti dalam melakukan beberapa kegiatan pembelajaran demi tercapainya pembelajaran yang berkualitas.

Judul penelitian tindakan kelas harus menggunakan kata predikat berupa meningkatkan atau peningkatan. Kata yang digunakan dalam pemilihan judul akan memberikan pengetahuan sekilas lebih awal untuk pembaca. Dianjurkan untuk mencari tidak hanya informasi judul yang berhubungan langsung dengan masalah tetapi juga untuk mengeksplorasi konsep yang terkait dengan masalah (Hathaway $\&$ Norton, 2018). Judul yang ditulis dengan menggunakan model atau metode pembelajaran akan menunjukkan peningkatan proses pembelajaran jika kegiatan pembelajaran hanya dilakukan secara konvensional.

\section{IDENTIFIKASI MASALAH}

Identifikasi masalah yang dilakukan dalam penelitian tindakan kelas memerlukan fokus dan konsentrasi dari peneliti supaya lebih cermat. Penelitian tindakan kelas adalah kegiatan mencermati pembelajaran dengan disertai sebuah tindakan yang dilakukan di dalam kelas secara bersama (Rismen, Delyana, Paramitha, Dan, \& Suryani, 2018). Sebagai langkah pertama untuk membiasakan diri dengan ide yang digunakan maka peneliti harus memilah yang mana yang dapat dijadikan identifikasi sumbernya (Harris, 2020). Identifikasi masalah merupakan suatu cara untuk menuliskan pernyataan-pernyataan masalah yang berada di dalam latar belakang masalah. Dalam 
proses mendefinisikan masalah, peneliti harus menghindari kesalahan dalam mengacaukan masalah (Hathaway \& Norton, 2018). Identifikasi masalah ditulis dengan mengaitkan masalah-masalah dan dijelaskan dengan berbagai sumber atau studi literatur.

Dibutuhkan pengetahuan yang cukup tentang suatu topik untuk mengidentifikasi jenis masalah yang cenderung memberikan kontribusi penting pada penelitian (Leedy \& Ormrod, 2021). Identifikasi masalah ditulis berupa kalimat-kalimat pernyataan yang menunjukan masalah. Hal yang membuat pembaca bingung akan menyebabkan mereka mempertanyakan ide dan masalah yang telah dituliskan (Creswell \& Creswell, 2018). Oleh karena itu, peneliti harus bisa mengkaitkan kesesuaian antara ide dan masalah. Penelitian tindakan kelas difokuskan pada masalah dalam konteks yang spesifik dan tidak mengambil pengetahuan ilmiah yang dapat digeneralisasikan (Rahardjo, 2015). Masalah yang spesifik dari penelitian tindakan kelas mengarah pada fokus kegiatan pembelajaran yang dialami guru dan siswa.

Rancangan penelitian tindakan kelas tidak hanya berdampak pada masalah dan hasil penelitian saja tetapi pemilihan tersebut memiliki rangkaian alur yang komplek. Penelitian tindakan kelas diselenggarakan secara kolaboratif dimulai mengidentifikasi masalah, mendiagnosa keadaan, merancang tindakan, mengumpulkan data, menganalisis data, dan merefleksi hasil temuan serta laporan (Nurdin, 2016). Oleh karena itu, penelitian ini memiliki rangkaian alur yang cukup panjang. Penelitian tindakan kelas tidak hanya difokuskan pada mengidentifikasi masalah tetapi juga difokuskan menyelesaikan masalah disertai melakukan perubahan dan perbaikan (Prihantoro \& Hidayat, 2019). Upaya perbaikan yang dilakukan ditentukan oleh pemilihan dan identifikasi masalah yang tepat.

Rancangan penelitian tindakan kelas akan menentukan terhadap masalah-masalah yang ditulis dan diidentifikasi. Pemilihan penelitian tindakan kelas akan menyebabkan banyak masalah yang dilakukan dalam proses kegiatan pembelajaran (Susilowati, 2018). Masalah yang 
didapatkan dari kegiatan pembelajaran dapat diidentifikasi dan diteliti. Penelitian tindakan kelas dilakukan berdasarkan masalah dari proses pembelajaran (Supriyanto, 2020). Masalah proses pembelajaran yang diteliti dengan penelitian tindakan kelas diharapkan ada peningkatan dari hasil belajar siswanya salah satunya. Penelitian tindakan kelas adalah penelitian yang diselenggarakan tentang masalah yang dialami guru dan dilaksanakan guru di kelasnya sendiri (Rismen et al., 2018). Peneliti harus bekerja sama dengan guru kelas yang mengetahui permasalahan tersebut supaya guru tidak mengalami kesusahan dalam pengambilan data dan menjelaskan masalah dari sudut pandang peneliti.

\section{RUMUSAN MASALAH}

Rumusan masalah adalah suatu cara yang digunakan dalam menulis kalimat yang menanyakan masalah dan didapatkan dari latar belakang masalah. Rumusan masalah ditulis berupa kalimat pertanyaan yang berkaitan dengan judul dan permasalahan penelitian. Tidak ada yang bisa mengajukan pertanyaan penelitian tanpa paparan serius terhadap disiplin ilmu dan topik yang menarik (Gatrell, Bierly, Jensen, \& Thakur, 2020). Pertanyaan yang ditulis di rumusan masalah harus disertai pemahaman struktur kalimat. Pemilihan kalimat pertanyaan tersebut tentunya berdasarkan dari kualitas pemahaman bahasa yang dikuasai peneliti. Pertanyaan yang ditulis akan menimbulkan rasa penasaran pembaca. Memilih masalah penelitian atau pertanyaan yang baik membutuhkan keingintahuan yang tulus tentang pertanyaan yang belum terjawab (Leedy \& Ormrod, 2021). Oleh karena itu, penulisan kalimat pertanyaan di rumusan masalah akan mempengaruhi minat pembaca.

Rumusan masalah ditulis berupa kalimat-kalimat pertanyaan yang menanyakan solusi dari masalah. Penelitian tindakan kelas dilakukan untuk menyelesaikan persoalan yang membutuhkan pemecahan (Huda, 2020). Persoalan dan pertanyaan yang dipecahkan dengan disertai tindakan peningkatan akan membutuhkan suatu ketrampilan. 
Pertanyaan umum tentang masalah penting bisa membutuhkan upaya dan keterampilan yang signifikan untuk menyempurnakan proyek penelitian yang bermanfaat (Harris, 2020). Penelitian tindakan kelas diharapkan dapat memberikan manfaat yang besar bagi guru untuk meningkatkan kegiatan mengajarnya menuju lebih baik.

Kata dan kalimat yang akan dituliskan di rumusan masalah harus mempertimbangkan variabel penelitian yang sudah ditulis. Rumusan masalah ditulis dengan mengaitkan variabel bebas dan variabel terikat. Variabel yang digunakan dalam penelitian tindakan kelas menggunakan variabel permasalahan dan tindakan (Susanti, 2017). Variabel-variabel tersebut bisa ditulis dengan pertanyaan yang berkaitan dengan penelitian tindakan kelas yang dilaksanakan baik di dalam maupun luar kelas. Penelitian tindakan kelas dapat dilakukan secara kolaboratif supaya masalah-masalah dapat diselesaikan dengan lebih komprehennsif (Prihantoro \& Hidayat, 2019). Masalahmasalah tersebut juga harus ditanyakan sesuai dengan karakter pertanyaan penelitian tindakan kelas.

Jawaban-jawaban dari rumusan masalah diharapkan menyelesaikan masalah yang didapatkan dari penelitian tindakan kelas. Penelitian tindakan kelas dilakukan untuk menyelesaikan permasalahan siswa dan kegiatan belajar yang dilaksanakan di kelas (Heriyawati \& Sari, 2020). Permasalahan siswa dapat diketahui ketika guru sedang mengajar. Penelitian tindakan kelas mempunyai problem masalah yang diambil dari kejadian seharian dan masalah tersebut didapatkan guru (Susilowati, 2018). Masalah yang dihadapi guru dalam mengajar memang dapat diteliti untuk ditingkatkan. Hal tersebut dapat menjadi solusi bagi guru untuk meningkatkan kualitas kegiatan proses pembelajaran. Penelitian tindakan kelas diharapkan memiliki penyelesaian terhadap permasalahan pembelajaran di kelas (Nurdin, 2016). Oleh karena itu praktek pembelajaran yang dilakukan para siswa diharapkan mengarah menuju pembelajaran aktif, kreatif, inovatif, efektif, dan menyenangkan. 


\section{DAFTAR PUSTAKA}

Creswell, J. W., \& Creswell, J. D. (2018). Research Design Qualitative, Quantitative, and Mixed Methods Approaches. Los Angeles: SAGE Publications.

Gatrell, J. D., Bierly, G. D., Jensen, R. R., \& Thakur, R. R. (2020). Research Design and Proposal Writing in Spatial Science. Cham: Springer Nature Switzerland AG.

Harris, D. (2020). Literature Review and Research Design. New York: Routledge.

Hathaway, D., \& Norton, P. (2018). Understanding Problems of Practice A Case Study in Design Research. Cham: Springer Nature Switzerland AG.

Heriyawati, D. F., \& Sari, I. N. (2020). Pelatihan Penulisan Penelitian Tindakan Kelas (PTK) pada Guru Sekolah Dasar di Kecamatan Sukun Kota Malang. Amalee: Indonesian Journal of Community Research and Engagement, 1(2), 101-111. https:// doi.org/10.37680/amalee.v1i2.302

Huda, F. A. (2020). Pengertian dan Konsep Penelitian Tindakan. Retrieved June 3, 2021, from www. fatkhan.web.id

Leedy, P. D., \& Ormrod, J. E. (2021). Practical Research Planning And Design. London: Pearson.

Nurdin, S. (2016). Guru Profesional Dan Penelitian Tindakan Kelas. Jurnal Educative: Journal of Educational Studies (Vol. 1). https://doi.org/10.30983/EDUCATIVE.V1I1.118

Prihantoro, A., \& Hidayat, F. (2019). Melakukan Penelitian Tindakan Kelas. Ulumuddin : Jurnal Ilmu-Ilmu Keislaman, 9(1), 49-60. https://doi.org/10.47200/ulumuddin.v9i1.283

Rahardjo, M. (2015). Penelitian Tindakan Kelas (PTK): Bolehkan untuk Menyusun Tesis atau Disertasi? Retrieved June 2, 2021, from 
https://www.uin-malang.ac.id/r/150301/penelitian-tindakankelas-ptk-bolehkan-untuk-menyusun-tesis-atau-disertasi. html

Rismen, S., Delyana, H., Paramitha, A., Dan, M., \& Suryani, M. (2018). Workshop Pelaksanaan Penelitian Tindakan Kelas Pada Musyawarah Guru Mata Pelajaran (Mgmp) Matematika Kota Solok, Sumatera Barat. Jurnal Pengabdian Masyarakat (Vol. 1). Retrieved from https://journal.uniku.ac.id/index.php/ empowerment/article/view/1515

Supriyanto, E. (2020). Penelitian Tindakan Kelas. Retrieved June 4, 2021, from https://sdit-abubakar.sch.id/penelitian-tindakankelas-eko-supriyanto/

Susanti, O. Y. (2017). Penelitian Tindakan Kelas : Upaya Meningkatkan Kemampuan Menanya Siswa melalui Literasi Informasi Mata Pelajaran IPS. Hermeneutika : Jurnal Hermeneutika, 3(2), 27. https://doi.org/10.30870/hermeneutika.v3i2.3085

Susilowati, D. (2018). Penelitian Tindakan Kelas Solusi Alternatif Problematika Pembelajaran. Jurnal Ilmiah Edunomika, 2(01). https://doi.org/10.29040/jie.v2i01.175

\section{BIOGRAFI}

Bayu Purbha Sakti bekerja sebagai dosen yang menghasilkan guru sekolah dasar. Beliau bekerja sebagai dosen swasta yayasan di Universitas Widya Dharma Klaten. Beliau menyelesaikan kuliah sebagai mahasiswa negeri. Beliau menyelesaikan kuliah sarjana dan magister di Universitas Negeri Yogyakarta. Beliau mengerjakan skripsi di sekolah dasar swasta. Beliau mengerjakan tesis di beberapa

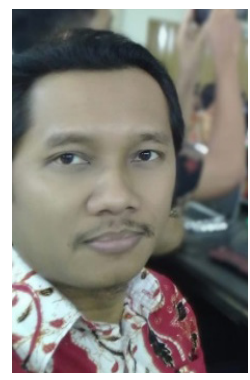
sekolah dasar negeri. Beliau mendedikasikan pekerjaan untuk mendidik calon guru dengan memfokuskan mengajar mata kuliah 
penelitian tindakan kelas. Beliau memiliki pengalaman mengajar di sekolah dasar selama 5 tahun. Beliau juga memiliki pengalaman mengajar di sekolah menengah pertama selama 2 tahun. Beliau sudah memiliki pengalaman dalam dunia pendidikan baik di kelas, lapangan, dan lingkungan dinas. 
Penelitian tindakan kelas (PTK) sangat familiar dalam karir dan aktifitas seorang guru. Kegiatan penelitian tindakan kelas dilakukan dengan tujuan untuk mendapatkan hasil belajar yang optimal. Melalui penelitian tindakan kelas, seorang guru dapat mengetahui efektifitas pembelajaran yang telah dilakukannya. Selain itu penelitian tindakan kelas juga memberi informasi penting kepada guru tentang segala sesuatu yang berkaitan dengan pembelajaran yang dilakukan.

Penelitian tindakan kelas penting untuk dilakukan oleh semua guru yang menginginkan adanya perbaikan kualitas pembelajaran. $\mathrm{Hal}$ ini tentu membutuhkan buku pedoman tentang penelitian tindakan kelas yang benar. Dalam buku ini, dibahas mengenai seluruh hal yang berkaitan dengan penelitian tindakan kelas. Mulai dari definisi PTK, tujuan PTK, bentuk PTK, PTK dan pengembangan profesi, perbedaan PTK dengan penelitian lainnya, proposal PTK, tahapan PTK, Identifikasi masalah, hipotesis tindakan, Faktor pendukung dan penghambat, kajian pustaka, metode penelitian, pengumpulan data, analisis data, evaluasi dan tindak lanjut, kesimpulan dan saran, laporan PTK. Harapan dari diterbitkannya buku ini bisa digunakan sebagai pedoman baik dari segi teori dan penerapan PTK bagi guru, dosen dan pelaku pendidikan lainnya yang sedang mempelajari dan menjalankan PTK

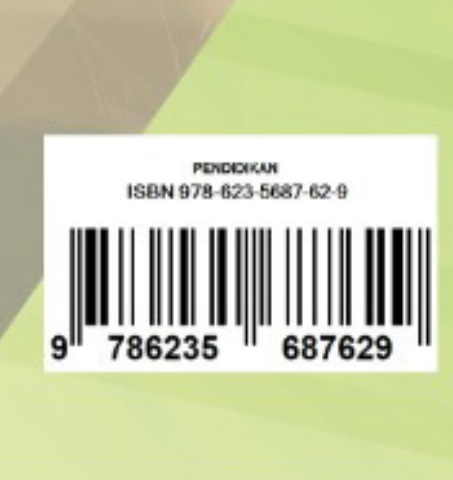

